\title{
Phylogeography of msp4 genotypes of Anaplasma marginale in beef cattle from the Brazilian Pantanal
}

\author{
Filogeografia de genótipos msp4 de Anaplasma marginale em gado de corte no Pantanal brasileiro \\ Inalda Angélica de Souza Ramos ${ }^{1}$; Heitor Miraglia Herrera ${ }^{2}$; Natália Serra Mendes ${ }^{1}$; \\ Simone de Jesus Fernandes'; João Bosco Vilela Campos²; João Vitor Almeida Alves²; \\ Gabriel Carvalho de Macedo $^{2}$; Rosangela Zacarias Machado ${ }^{1}$; Marcos Rogério André ${ }^{1 *}$

\begin{abstract}
${ }^{1}$ Departamento de Patologia Veterinária, Faculdade de Ciências Agrárias e Veterinárias, Universidade Estadual Paulista "Júlio de Mesquita Filho" - UNESP, Jaboticabal, SP, Brasil

${ }^{2}$ Departamento de Parasitologia Veterinária, Universidade Católica Dom Bosco - UCDB, Campo Grande, MS, Brasil
\end{abstract}

Received March 27, 2019

Accepted May 16, 2019

\begin{abstract}
The msp4 gene of $A$. marginale is unicodon, stable and mostly homogeneous, being considered as a useful marker for phylogeographic characterization of this bacterium. The objective of this work was to analyze the phylogeography of $A$. marginale based on the msp4 gene in beef cattle from the Brazilian Pantanal, compared to those found in other regions worldwide. The blood samples investigated were collected from 400 animals (200 cows and 200 calves) reared in five extensive breeding farms in this region. The results indicated that of the evaluated samples, 56.75\% (227/400) were positive for $A$. marginale based on the msp $1 \beta$ gene by quantitatitve PCR (qPCR), while $8.37 \%$ (19/227) were positive for the msp 4 gene in the conventional PCR. In the Network distance analysis, 14 sequences from the Brazilian Pantanal were grouped into a single group with those from Thailand, India, Spain, Colombia, Parana (Brazil), Mexico, Portugal, Argentina, China, Venezuela, Australia, Italy and Minas Gerais (Brazil). Among 68 sequences from Brazil and the world, 15 genotypes were present while genotype number one (\#1) was the most distributed worldwide. Both Splitstree and network analyses showed that the $A$. marginale msp 4 sequences detected in beef cattle from the Brazilian Pantanal showed low polymorphism, with the formation of one genogroup phylogenetically related to those found in ruminants from South and Central America, Europe, and Asia.
\end{abstract}

Keywords: Bovine anaplasmosis, geographic distribution, msp4, nelores.

\section{Resumo}

O gene msp4 de $A$. marginale é unicodon, estável e pouco heterogêneo, sendo considerado como um marcador útil para caracterização filogeográfica desta bactéria. Este trabalho teve como objetivo analisar a filogeografia de $A$. marginale com base no gene msp 4 em bovinos de corte do Pantanal Brasileiro, comparativamente a outra regióes do mundo. Alíquotas de sangue foram colhidas de 400 bovinos (200 vacas e 200 bezerros) em cinco propriedades de cria e recria extensiva. Como resultado, 56,75\% (227/400) mostraram-se positivas para $A$. marginale pela qPCR para o gene $m s p 1 \beta$ e destas, 8,37\% (19/227) amostras foram positivas na PCR convencional para o gene msp4. Na análise de distância Network, 14 sequências do Pantanal brasileiro foram agrupadas em um único grupo com as da Thailândia, Índia, Espanha, Colômbia, Paraná (Brasil), México, Portugal, Argentina, China, Venezuela, Austrália, Italia e Minas Gerais (Brasil). Dentre 68 sequências do gene msp4 do Brasil e do mundo, constatou-se a presença de 15 genótipos, sendo o genótipo número um (\#1) o mais distribuído. As sequências msp4 de $A$. marginale detectadas em bovinos de corte no Pantanal brasileiro apresentaram baixo polimorfismo com formaçáo de dois genogrupos filogeneticamente relacionados àqueles encontrados em ruminantes de países das América do Sul e Central, Europa e Ásia.

Palavras-chave: Anaplasmose bovina, distribuição geográfica, $m s p 4$, nelores.

\footnotetext{
*Corresponding author: Marcos Rogério André. Laboratório de Imunoparasitologia, Departamento de Patologia Veterinária, Faculdade de Ciências Agrárias e Veterinárias, Universidade Estadual Paulista "Júlio de Mesquita Filho" - UNESP, Campus de Jaboticabal, Via de Acesso Prof. Paulo Donato Castellane, s/n, Zona Rural, CEP 14884-900, Jaboticabal, SP, Brasil. e-mail: marcosandre.fcav@gmail.com
} 


\section{Introduction}

Anaplasma marginale is an intra-erythrocyte bacterium that infects cattle causing the affected animals to gain little weight, reduced milk production, abortion, incurring in treatment expenses and mortality, being, therefore responsible for great economic losses worldwide (KOCAN et al., 2003). Brazil is considered endemic to $A$. marginale because the molecular prevalence in domestic ruminants can vary from $7.5 \%$ to $100 \%$ (SILVA et al., 2016).

Among the main beef producing regions, the municipality of Corumbá in the Brazilian Pantanal region has the second largest cattle population in Brazil, with 1.9 million animals (ALHO, 2005; ABREU et al., 2008). The Pantanal is the largest wetland of the world, occupying areas in Brazil, Paraguay and Bolivia, whose main economic activity is the extensive production of beef cattle (ABREU et al., 2008).

The genetic characterization of $A$. marginale has been crucial for the development and implementation of epidemiological studies and strategies for controlling bovine anaplasmosis. In this regard, major surface proteins (MSPs) of $A$. marginale involved in the interaction with vertebrate host cells and vector ticks have been used as genetic markers for characterizing the strains of said agent around the world (PALMER et al., 1999; CABEZAS-CRUZ et al., 2013). Sequences of the $m s p 4$ gene, which is responsible for encoding the MSP4 immunogenic protein (MOLAD et al., 2009), showed phylogeographic relationships among the $A$. marginale isolates from Mexico, Brazil, Argentina, Australia and India, suggesting similar evolutionary processes among these isolates (DE LA FUENTE et al., 2004; GEORGE et al., 2017).

Although studies on the diversity of $A$. marginale strains based on the mspl $\alpha$ gene have been conducted in dairy herds in several Brazilian states, such as Paraná (VIDOTTO et al., 2006; BAÊTA et al., 2015; SILVA et al., 2015), Minas Gerais (POHL et al., 2013), São Paulo (MACHADO et al., 2015; SILVA et al., 2016), and Goiás (Mambaí) (MACHADO et al., 2015), phylogeographic studies of $A$. marginale isolates based on the $m s p 4$ gene are scarce in Brazil.

Therefore, this work aimed at analyzing the phylogeography of Brazilian A. marginale isolates based on the $m s p 4$ gene in order to understand the genetic characteristics of this bacterium population in Brazil compared to other regions of the world.

\section{Materials and Methods}

\section{Animals and study area}

We sampled beef cattle (Bos taurus indicus) from five breeding and rearing farms in the Central Region of the Pantanal Sul Matogrossense, in the Nhecolândia Sub-region (Table 1). For this purpose, blood samples were collected from 400 animals (200 cows and 200 calves) for a cross-sectional study approved by the National Council for Control of Animal Experimentation (CONCEA) and by the Ethics Committee on Animal Use (CEUA, FCAV, UNESP, Protocol No. 12375/15)

\section{Blood sampling}

Whole blood samples were collected directly from the caudal vein, stored in EDTA (Ethylenediamine Tetra - Sodium Acetic Acid $300 \mathrm{mmol} / \mathrm{L}$ ) anticoagulant tubes and used for DNA extraction and subsequent Polymerase Chain Reaction (PCR).

\section{DNA extraction}

The DNA from bovine whole blood samples was extracted following the protocol previously described by Kuramae-Izioka (1997).

\section{Amplification reaction for the mammal-endogenous glyceraldehyde-3-phosphate dehydrogenase gene (gapdh)}

To verify the presence of inhibitors in the DNA samples, a standard PCR assay for the mammal endogenous gapdh gene was performed, following the protocol previously established by Birkenheuer et al. (2003).

\section{Quantitative real-time PCR ( $q P C R$ ) for $A$. marginale (msp1 $1 \beta$ gene)}

The samples positive for $A$. marginale in the conventional PCR based on the gapdh gene were also submitted to quantitative real-time PCR (qPCR) based on the msp1 $\beta$ gene, according to the protocol described by Carelli et al. (2007), with modifications (SOUZA RAMOS et al., 2019).

\section{Conventional PCR (cPCR) for A. marginale based on the msp4 gene}

The samples positive for $A$. marginale in qPCR were submitted to cPCR based on the msp 4 gene, using a protocol previously described by De la Fuente et al. (2002). The reaction with a final volume of $25 \mu \mathrm{L}$ contained $5 \mu \mathrm{L}$ of genomic DNA, 10X concentrated buffer, $0.75 \mathrm{mM} \mathrm{MgCl}_{2}, 1.25 \mu \mathrm{M}$ of each primer oligonucleotide the msp 45 (5'-GGGAGCTCCTATGAATTACAGAGAATTGTTTAC-3') and

Table 1. Studied farms and number (n) of beef cattle (cows and calves) sampled between August 2016 and April 2017 in the Brazilian Pantanal.

\begin{tabular}{|c|c|c|c|c|c|}
\hline Farm & Latitude & Longitude & Cows (n) & Calves (n) & Total (n) \\
\hline${ }^{*}$ Farm A & $19^{\circ} 08^{\prime} 34^{\prime \prime} \mathrm{S}$ & $56^{\circ} 47^{\prime} 35^{\prime \prime} \mathrm{W}$ & 45 & 53 & 98 \\
\hline${ }^{*}$ Farm S & $19^{\circ} 16^{\prime} 27^{\prime \prime} \mathrm{S}$ & $56^{\circ} 38^{\prime} 16^{\prime \prime} \mathrm{W}$ & 42 & 41 & 83 \\
\hline${ }^{*}$ Farm P & $18^{\circ} 54^{\prime} 26^{\prime \prime} \mathrm{S}$ & $56^{\circ} 31^{\prime} 23^{\prime \prime} \mathrm{W}$ & 39 & 41 & 80 \\
\hline${ }^{* *} \operatorname{Farm} \mathbf{N}$ & $19^{\circ} 15^{\prime} 08^{\prime \prime} \mathrm{S}$ & $57^{\circ} 03^{\prime} 44^{\prime \prime} \mathrm{W}$ & 38 & 34 & 72 \\
\hline${ }^{* *}$ Farm C & $19^{\circ} 09^{\prime} 19 ” \mathrm{~S}$ & $57^{\circ} 50^{\prime} 42^{\prime \prime} \mathrm{W}$ & 36 & 31 & 67 \\
\hline Total & & & 200 & 200 & 400 \\
\hline
\end{tabular}

*First sampling (August/2016); **Second sampling (April/2017). 
msp43- (5'-CCGGATCCTTAGCTGAACAGGAATCTTGC -3') (Integrated DNA Technologies ${ }^{\circledR}$, Cedar Rapids, USA), $0.2 \mu \mathrm{M}$ deoxynucleotide triphosphates (dNTPs), 0.1 UTaq DNA Polymerase Platinum (Thermofisher Scientific ${ }^{\circledR}$, Carlsbad, California, USA) and sterile ultra-pure water (Nuclease-Free Water, Promega ${ }^{\circledR}$, Madison, Wisconsin, USA) q.s.p. The used thermal sequence comprised initial denaturation at $94^{\circ} \mathrm{C}$ for 30 seconds, 35 cycles of $94^{\circ} \mathrm{C}$ for 30 seconds, $60^{\circ} \mathrm{C}$ for 30 seconds, $72^{\circ} \mathrm{C}$ for 1 minute, followed by a final extension at $72^{\circ} \mathrm{C}$ for 5 minutes.

\section{Purification and sequencing of amplified products}

The amplified products were purified with Silica Bead DNA Gel Extraction Kit (Thermo Scientific ${ }^{\circledR}$, San Jose, CA, USA) according to the manufacturer's recommendations. The sequencing of the purified products was performed using an automated system based on the dideoxynucleotide chain termination method (SANGER et al., 1977). The process was carried out using the ABI PRISM 3700 DNA Analyzer (Applied Biosystem ${ }^{\circledR}$, Foster City, CA, USA), in the Technology Department of the College of Agrarian and Veterinary Sciences (FCAV/UNESP), Center for Biological Resources and Genomic Biology (CREBIO), using the same oligonucleotides employed in the CPCR assay for detecting A. marginale based on the msp 4 gene (1733F and 2957R2) (Integrated DNA Technologies ${ }^{\circledR}$, Cedar Rapids, USA).

\section{Analysis of the nucleotide and amino acid sequences of the A. marginale msp4 gene}

Sequencing analysis was performed by the Phred/Phrap/Consed software (EWING \& GREEN, 1998), which evaluates the electropherograms generated in the sequencing, observing the quality of the peaks corresponding to each sequenced base and assigning an error probability to each one of the samples. Bases with Phred-quality above 20 were used in the subsequent genotype analyses. The consensus sequences were also generated by Phred/Phrap/Consed. The BLASTn software (ALTSCHUL et al., 1990) was used to compare the identity of the obtained nucleotide sequences with those stored in the international databases (GenBank) (http://www.ncbi.nlm.nih.gov/genbank) (BENSON et al., 2002).

\section{Genotype diversity}

The alignment of nucleotide sequences of the $m s p 4$ gene obtained in the present study was used to calculate the nucleotide diversity $(\pi)$, polymorphism level (genotype diversity - $[\mathrm{DH}])$, number of genotypes (h) and mean number of nucleotide differences $(K)$ using the DnaSP v5 software (LIBRADO \& ROZAS, 2009).

\section{Nucleotide distance analysis}

The network distance analysis of the msp 4 sequences detected in the present study was conducted together with 54 other sequences from several regions of the world and retrieved from GenBank, using the Splitstree software with the Neighbor-Net and Uncorrected p-distance parameters. The popART software was also used (LEIGH \& BRYANT, 2015).

\section{Results}

\section{Conventional PCR (cPCR) for mammal-gapdh endogenous gene}

All 400 DNA samples extracted from bovine blood were positive for the mammal-endogenous gene ( $g a p d h)$ in the CPCR, discarding the occurrence of false negative results due to PCR inhibitors. The assay was performed after the spectrophotometric evaluation of the average concentration and absorbance ratios (260/280 and 260/230 $\mathrm{nm}$ ) of the extracted DNA samples, which assumed values of $25.14 \mathrm{ng} / \mu \mathrm{L},(\mathrm{SD} \pm 10.14), 1.8 \mathrm{~nm}$ $(S D \pm 0.12)$, and $1.33 \mathrm{~nm}(S D \pm 0.56)$, respectively.

\section{Frequency of $A$. marginale positive animals in $q P C R$ based on the msp1 $\beta$ gene}

Out of the $400 \mathrm{cPCR}$ positive samples for the endogenous gene (gapdh), 56.75\% (227/400) were positive for $A$. marginale in qPCR based on the msp $1 \beta$ gene, of which $39.20 \%(89 / 227)$ were cows and $60.79 \%(138 / 227)$, calves.

\section{cPCR for the A. marginale msp4 gene}

Of the animals positive in the qPCR, 8.37\% (19/227) samples were positive for the $m s p 4$ gene. A total of 14 were sequenced based on the intensity of the DNA bands on agarose gel, 4 cows and 10 calves from Farm A. The rickettsesia of positive animals (number of $m s p 1 \beta$ copies $/ \mu \mathrm{L}$ of blood) ranged from $4.42 \times 10^{4}$ (MS13-calf) to $8.33 \times 10^{9}$ (MS1-cow) (Table 2).

Table 2. Samples of cows and calves $(n=14)$ from the Brazilian Pantanal, cPCR positive for the Anaplasma marginale ms $p 4$ gene with their respective tag and quantity (qPCR based on the $m s p 1 \beta$ gene).

\begin{tabular}{|c|c|c|c|}
\hline Sample & Label & Farm & $\begin{array}{c}\text { Absolute } \\
\text { Quantification vy } \\
\text { qPCR } \\
(m s p 1 \beta / \mu \mathrm{L})\end{array}$ \\
\hline MS1 & V3 & Farm A & $8.33 \times 10^{9}$ \\
\hline MS2 & V8 & Farm A & $1.97 \times 10^{5}$ \\
\hline MS3 & V10 & Farm A & $2,20 \times 10^{6}$ \\
\hline MS4 & $\mathrm{B} 1$ & Farm A & $5.25 \times 10^{5}$ \\
\hline MS5 & B2 & Farm A & $1.86 \times 10^{5}$ \\
\hline MS6 & B3 & Farm A & $9.53 \times 10^{5}$ \\
\hline MS7 & B8 & Farm A & $6.86 \times 10^{5}$ \\
\hline MS8 & B10 & Farm A & PM \\
\hline MS9 & B33 & Farm A & $1.52 \times 10^{6}$ \\
\hline MS10 & B37 & Farm A & $1.57 \times 10^{6}$ \\
\hline MS11 & B42 & Farm A & $\mathrm{PM}^{*}$ \\
\hline MS12 & B44 & Farm A & $\mathrm{PM}^{*}$ \\
\hline MS13 & B46 & Farm A & $4.42 \times 10^{4}$ \\
\hline MS14 & V14 & Farm A & $\mathrm{PM}^{*}$ \\
\hline
\end{tabular}

$\mathrm{PM}^{*}=$ Positive for the Monte Carlo effect (with low DNA template). 


\section{Anaplasma marginale genotypes based on the msp4 gene}

Among the 14 nucleotide sequences of the msp4 gene obtained in the present study, 1 genotype were identified, with $\pi=0.00024 \pm 0.0020 \mathrm{DH}=0.1429 \pm 0.00011029$ and $\mathrm{K}=0.14286$. Among the $68 \mathrm{msp} 4$ gene sequences analyzed (corresponding to those detected in the present study and others retrieved from the GenBank), 15 genotypes were identified, with a polymorphism of $\mathrm{DH}=0.6558 \pm 0.062$ and $\mathrm{K}=2.44$ (Table 3 ).

\section{Nucleotide distance analysis and genotype network}

The distance analysis using Splitstree software with the "Neighbor-Net" and "Uncorrected p-distance" parameters showed that the 14 msp4 sequences of $A$. marginale detected in beef cattle in the Brazilian Pantanal were grouped into a single group with those previously detected in Thailand, India, Spain, Colombia, Parana (Brazil), Mexico, Portugal, Argentina, China, Venezuela, Australia, Italy and Minas Gerais (Brazil) (Figure 1). In the Brazilian Pantanal, only one genotype (\#1) was found. The analysis of the 68 sequences by the software DnaSP v 5 indicated 15 genotypes, being genotype \# 1 the most distributed, since it has been detected in cattle in 12 countries (Brazil [Pantanal-MS, Minas Gerais and Paraná], Mexico, Venezuela, Colombia, Argentina, Thailand, China, Portugal, Italy, Spain, Australia and India), followed by genotype \#8 detected in 5 countries (Sudan, Japan, South_Africa, Spain, Australia), genotype \#5 found in 4 countries (Switzerland, Italy, Turkey and Israel), and genotype \#6 found in cattle from 2 countries (USA and Iran). Genotype \#1, corresponding to the majority $(57.35 \% ; 39 / 68)$ of the $m s p 4$ sequences detected in cattle in the world and also the only one found in beef cattle in the Brazilian Pantanal, showed to be related to genotypes \#3, \#4 and \#11, respectively, detected in cattle in Mexico, Italy and Mexico. Genotype \#1 showed to be distant from genotypes \#7 and \#10, detected in cattle from the USA and Sudan, respectively (Figure 2).

\section{Discussion}

Herein, the qPCR assay based on the $m s p 1 \beta$ gene was chose for the screening for $A$. marginale in beef cattle blood samples collected in the Brazilian Pantanal due to its high reprodutibility, specificity and sensitivity ( $10^{1}$ DNA copies/10 $\mu \mathrm{l}$ of standard DNA and erythrocytes infected with $3 \times 10^{1}$ A. marginale $/ \mathrm{mL}$ ) (CARELLI et al., 2007; SOUZA RAMOS et al., 2019). Therefore, the incongruent results found between the qPCR and cPCR assays used in the present study, based on $m s p 1 \beta$ and $m s p 4$ genes, respectively, are mainly due to the highest sensitivity of the former compared to the latter.

The A. marginale msp 4 gene has been proposed as a molecular marker for studying the phylogeography of this

Table 3. Polymorphism and genetic diversity of Anaplasma marginale msp4 sequences detected in beef cattle sampled in the Brazilian Pantanal and in conjunction with those obtained via GenBank.

\begin{tabular}{lcccccccc}
\hline \multicolumn{1}{c}{ Species (target gene) } & PB & N & VS & GC $\%$ & H & DH $($ MEAN \pm SD) & $\pi(\mathbf{M E A N} \pm$ SD) & K \\
\hline $\begin{array}{l}\text { Anaplasma marginale Pantanal } \\
\text { (msp4) }\end{array}$ & 656 & 14 & 1 & 0.484 & $\mathbf{1}$ & $0.1429 \pm 0.00011029$ & $0.00024 \pm 0,0020$ & 0.14286 \\
$\begin{array}{l}\text { Anaplasma marginale } \\
\begin{array}{l}\text { world } \\
\text { (msp4) }\end{array}\end{array}$ & 639 & 68 & 13 & 48.4 & $\mathbf{1 5}$ & $0.6558 \pm 0.062$ & $0.00991 \pm 0.00123$ & 2.44 \\
\hline
\end{tabular}

PB = size of the nucleotide fragment; $\mathbf{N}=$ number of analyzed sequences; $\mathbf{V S}=$ number of variable sites; $\mathbf{G C}=\mathrm{G} \times \mathrm{C}$ content; $\mathbf{H}=$ number of genotypes; $\mathbf{D H}=$ diversity of genotypes; $\mathbf{S D}=$ standard deviation; $\pi=$ nucleotide diversity (per site = PI); $\mathbf{K}=$ mean number of nucleotide difference.

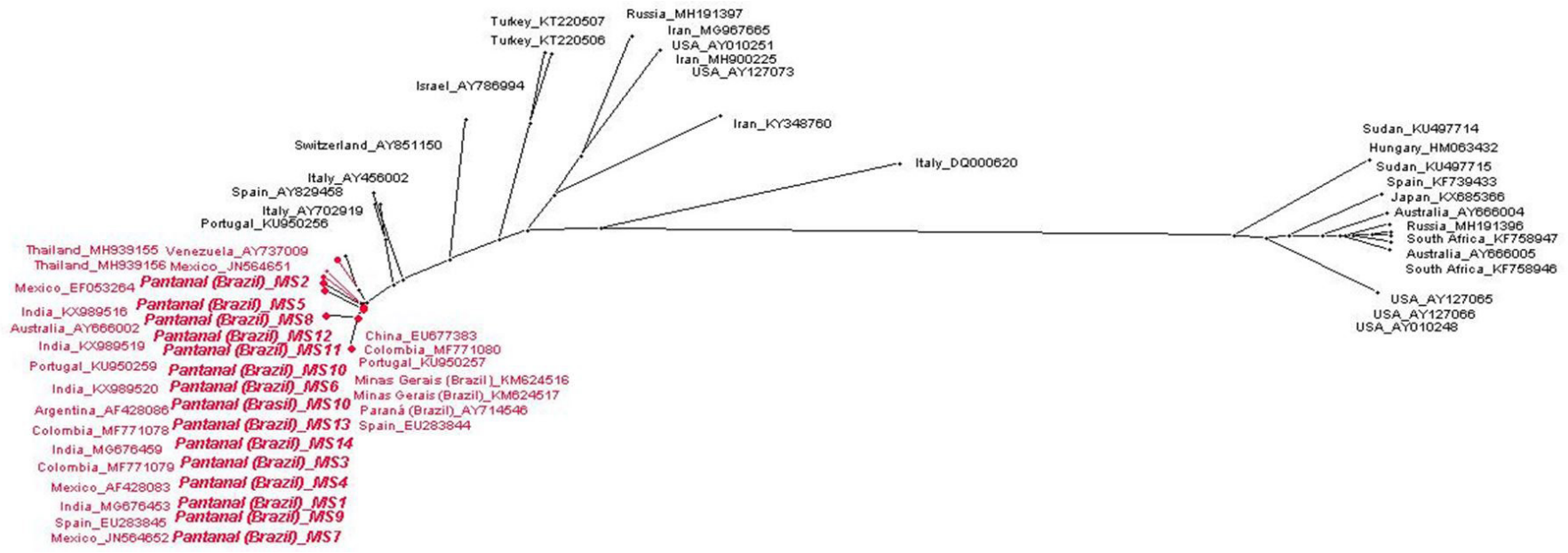

Figure 1. Distance analysis using the Splitstree software with the "Neighbor-Net" and "Uncorrected p-distance" parameters. Sequences of the msp4 gene from the Brazilian Pantanal formed a clade with sequences from Thailand, India, Spain, Colombia, Parana (Brazil), Mexico, Portugal, Argentina, China, Venezuela, Australia, Italy and Minas Gerais (Brazil). 


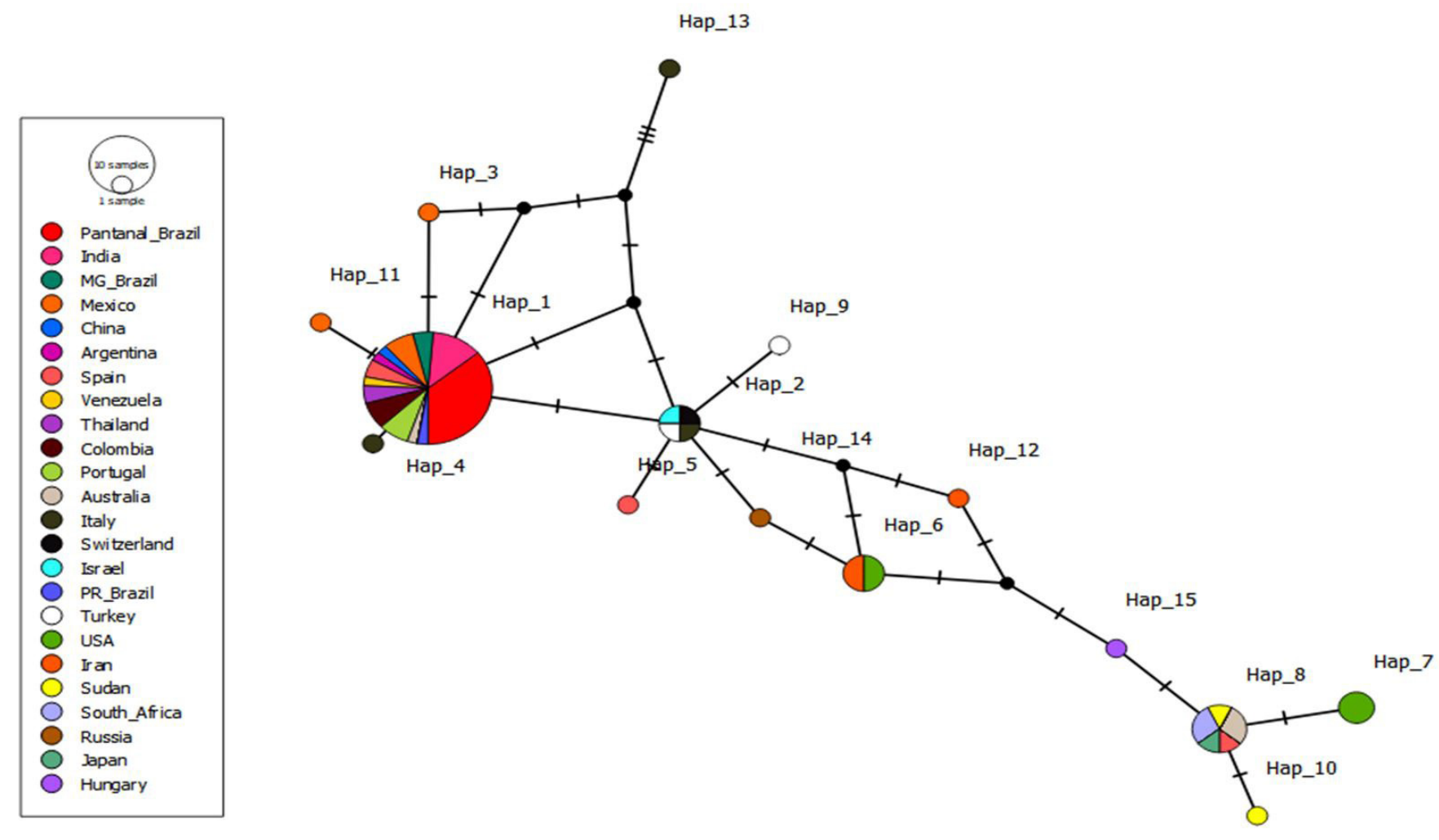

Figure 2. A network of Anaplasma marginale msp4 genotypes (Hap) detected in beef cattle sampled in the Brazilian Pantanal together with those obtained from the GenBank. Black spots represent median-vectors. Small traits between one genotype and another represent mutational events.

agent (DE LA FUENTE et al., 2001; GEORGE et al., 2017; MOLAD et al., 2009; VIDOTTO et al., 2006). The present study showed that $A$. marginale msp 4 genotypes detected in beef cattle from the Brazilian Pantanal are phylogeographically related to those circulating in countries from South and Central America, Europe, and Asia. De la Fuente et al. $(2002,2003,2004)$ reported that analyses based on the $m s p 4$ gene provide phylogenetic and phylogeographic information and data on the $A$. marginale samples. Jaimes-Dueñez et al. (2018) analyzed $A$. marginale samples phylogeographically and detected, in a longitudinal study with dairy cattle, that Colombian isolates were highly correlated with Mexican, Brazilian, Venezuelan, European and Asian isolates, suggesting a high genetic similarity between the strains from Mexico and South American countries. Vidotto et al. (2006) verified a high similarity between $A$. marginale msp 4 sequences detected in dairy cattle in Paraná and those from the USA, Europe, and Asia.

Vidotto et al. (2006) reported that the phylogeographic distribution of the $A$. marginale strains was better demonstrated and more uniform when the $m s p 4$ gene was analyzed compared to the mspl $\alpha$ gene. Recently, Souza Ramos et al. (2019) identified 14 A. marginale msp $1 \alpha$ strains in the same studied region, with eight never before described in the literature, showing a high genetic diversity of this agent based on a fast-evolving gene.

In this study, the $m s p 4$ gene was considered as a stable marker for the phylogenetic characterization of $A$. marginale samples, corroborating with De la Fuente et al. (2004). The 14 Pantanal msp 4 sequences clustered into one genotype (\#1), which represented the most frequent genotype detected around the world. In total,
15 A. marginale msp 4 genotypes were discriminated in the genotype network, which was performed with sequences detected in the present study together with others retrieved from GenBank and found in other regions of the world. Belkahia et al. (2015) reported that this heterogeneity could be partially explained by the importation of live cattle and/or the spread of infected ticks. Estrada-Peña et al. (2009) and Rodríguez-Vivas et al. (2014) suggested that the environmental conditions of each country could modulate the geographical distribution of genotypes, although studies related to the evolutionary history and epidemiological characteristics of these genotypes are still necessary to determine their importance for livestock.

Considering that $m s p 4$ is a conservative gene, it would be expected low values of variable sites (VS), diversity of genotypes $(\mathrm{DH})$, nucleotide diversity $(\pi)$, and mean number of nucleotide difference $(\mathrm{K})$ when a population of $A$. marginale genotypes would be evaluated in a certain geographic region. Interestingly, when A. marginale genotypes found in different countries were evaluated, higher values of genetic diversity were observed, showing an increase of 17 times in the mean number of nucleotide difference, and 41 times in the nucleotide diversity, with 13 variable sites. This finding might be associated with the different degrees of selection pressure imposed to the pathogen in each locality around the world. Albeit with low number when compared to more evolving genes (such as $m s p l \alpha$ ), the occurrence of mutational events throughout the evolutive history of $A$. marginale can be seen in genotype network presented in this manuscript. Future studies aiming at unravelling the "missed genotypes", represented by median-vectors 
in the genotype network, in Brazil and other parts of the world, are much needed aiming at elucidating the evolutionary history of $A$. marginale msp 4 genotypes.

\section{Conclusion}

The A. marginale msp4 sequences detected in beef cattle in the Brazilian Pantanal showed low polymorphism. The only one A. marginale msp4 genotype detected in cattle from the Brazilian Pantanal was phylogeographically related to those found in ruminants from South and Central America, Europe, and Asia. Studies related to the evolutionary history and epidemiological characteristics of these genotypes are still necessary to determine their importance for livestock.

\section{Acknowledgements}

The authors would like to thank the Graduate Program in Veterinary Medicine, Concentration in Animal Pathology (Universidade Estadual Paulista, UNESP, Jaboticabal), The FAPESP (Foundation for Research Support State of São Paulo - Process 2015/14896-1), FUNDECT (Foundation for Support to the Development of Education, Science and Technology of the State of Mato Grosso do Sul. Process 59/300.187/2016) and CNPq (2014/401.403.120.16-5) for the financial and technical support for conducting this research and for the Productivity grant given to MRA (CNPq Process \#302420/2017-7). The present study was carried out with the support of the Coordination of Improvement of Higher-Level Personnel-Brazil (CAPES) - Financing Code 001.

\section{References}

Abreu UGP, Gomes EG, Lopes PS, Torres RA, Santos HN. Avaliação sistêmica da introduçáo de tecnologias na pecuária de gado de corte do Pantanal por meio de modelos de análise envoltória de dados (DEA). Rev Bras Zootec 2008; 37(11): 2069-2076. http://dx.doi.org/10.1590/ S1516-35982008001100025.

Alho CJR. The Pantanal. In: Fraser LH, Keddy PA, editors. The world's largest Wetlands: ecology and conservation. Cambridge: Cambridge University Press; 2005. p. 203-271.

Altschul SF, Gish W, Miller W, Myers EW, Lipman DJ. Basic local alignment search tool. J Mol Biol 1990; 215(3): 403-410. http://dx.doi. org/10.1016/S0022-2836(05)80360-2. PMid:2231712.

Baêta BA, Ribeiro ACC, Teixeira ARC, Cabezas-Cruz A, Passos LMF Zweygarth E, et al. Characterization of two strains of Anaplasma marginale isolated from cattle in Rio de Janeiro, Brazil, after propagation in tick cell culture. Ticks Tick Borne Dis 2015; 6(2): 141-145. http://dx.doi. org/10.1016/j.ttbdis.2014.11.003. PMid:25468764.

Belkahia H, Ben Said M, Alberti A, Abdi K, Issaoui Z, Hattab D, et al. First molecular survey and novel genetic variants' identification of Anaplasma marginale, A. centrale and A. bovis in cattle from Tunisia. Infect Genet Evol 2015; 34: 361-371. http://dx.doi.org/10.1016/j.meegid.2015.06.017. PMid:26117444.

Benson DA, Karsch-Mizrachi I, Lipman DJ, Ostell J, Rapp BA, Wheeler DI. GenBank. Nucleic Acids Res 2002; 30(1): 17-20. http://dx.doi. org/10.1093/nar/30.1.17. PMid:11752243.
Birkenheuer AJ, Levy MG, Breitschwerdt EB. Development and evaluation of a seminested PCR for detection and differentiation of Babesia gibsoni (Asian genotype) and B. canis DNA in canine blood samples. J Clin Microbiol 2003; 41(9): 4172-4177. http://dx.doi.org/10.1128/ JCM.41.9.4172-4177.2003. PMid:12958243.

Cabezas-Cruz A, Passos LMF, Lis K, Kenneil R, Valdés JJ, Ferrolho $\mathrm{J}$, et al. Fuente Functional and immunological relevance of Anaplasma marginale major surface protein $1 \alpha$ sequence and structural analysis. PLoS One 2013; 8(6): e65243. http://dx.doi.org/10.1371/journal. pone.0065243. PMid:23776456.

Carelli G, Decaro N, Lorusso A, Elia G, Lorusso E, Mari V, et al. Detection and quantification of Anaplasma marginale DNA in blood sample of cattle by real-time PCR. Vet Microbiol 2007; 124(1-2): 107-114. http://dx.doi. org/10.1016/j.vetmic.2007.03.022. PMid:17466470.

De la Fuente J, Garcia-Garcia JC, Blouin EF, Rodríguez SD, Garcia MA, Kocan KM. Evolution and function of tandem repeats in the major surface protein $1 \alpha$ of the ehrlichial pathogen Anaplasma marginale. Anim Health Res Rev 2001; 2(2): 163-173. http://dx.doi.org/10.1079/ AHRR200132. PMid:11831437.

De la Fuente J, Passos LMF, Van Den Bussche RA, Ribeiro MFB, Facury-Filho EJ, Kocan KM. Genetic diversity and molecular phylogeny of Anaplasma marginale isolates from Minas Gerais, Brazil. Vet Parasitol 2004; 121(3-4):307-316. http://dx.doi.org/10.1016/j.vetpar.2004.02.021. PMid:15135871.

De la Fuente J, Van den Bussche RA, Garcia-Garcia JC, Rodríguez SD, García MA, Guglielmone A, et al. Phylogeography of New World isolates of Anaplasma marginale based on major surface protein sequences. Vet Microbiol 2002; 88(3): 275-285. http://dx.doi.org/10.1016/S03781135(02)00122-0. PMid:12151201.

De la Fuente J, Van Den Bussche RA, Prado T, Kocan KM. Anaplasma marginale msp $1 \alpha$ genotypes evolved under positive selection pressure but are not markers for geographic isolates. J Clin Microbiol 2003; 41(4): 1609-1616. http://dx.doi.org/10.1128/JCM.41.4.1609-1616.2003. PMid:12682152.

Estrada-Peña A, Naranjo V, Acevedo-Whitehouse K, Mangold AJ, Kocan KM, De la Fuente J. Phylogeographic analysis reveals association of tickborne pathogen, Anaplasma marginale, MSP1a sequences with ecological traits affecting tick vector performance. BMC Biol 2009; 7(1): 57. http:// dx.doi.org/10.1186/1741-7007-7-57. PMid:19723295.

Ewing B, Green P. Base-calling of automated sequencer traces using Phred II: error probabilities. Genome Res 1998; 8(3): 186-194. http://dx.doi. org/10.1101/gr.8.3.186. PMid:9521922.

George N, Bhandari V, Sharma P. Phylogenetic relationship and genotypic variability in Anaplasma marginale strains causing anaplasmosis in India. Infect Genet Evol 2017; 48: 71-75. http://dx.doi.org/10.1016/j. meegid.2016.11.028. PMid:27939332.

Jaimes-Dueñez J, Triana-Chávez O, Mejía-Jaramillo AM. Spatial-temporal and phylogeographic characterization of Trypanosoma spp. in cattle (Bos taurus) and buffaloes (Bubalus bubalis) reveals transmission dynamics of these parasites in Colombia. Vet Parasitol 2018; 249: 30-42. http://dx.doi. org/10.1016/j.vetpar.2017.11.004. PMid:29279084.

Kocan KM, De la Fuente J, Guglielmone AA, Meléndez RD. Antigens and alternatives for control of Anaplasma marginale infection in cattle. Clin Microbiol Rev 2003; 16(4): 698-712. http://dx.doi.org/10.1128/ CMR.16.4.698-712.2003. PMid:14557295.

Kuramae-Izioka EE. A rapid, easy and high yield protocol for total genomic DNA isolation of Colletotrichum gloeosporioides and Fusarium oxysporum. Rev Unimar 1997; 19(3): 683-689. 
Leigh JW, Bryant D. POPART: full-feature software for haplotype network construction. Methods Ecol Evol 2015; 6(9): 1110-1116. http://dx.doi. org/10.1111/2041-210X.12410.

Librado P, Rozas J. DnaSP v5: a software for comprehensive analysis of DNA polymorphism data. Bioinformatics 2009; 25(11): 1451-1452. http://dx.doi.org/10.1093/bioinformatics/btp187. PMid:19346325.

Machado RZ, Silva JB, André MR, Gonçalves LR, Matos CA, Obregón D. Outbreak of anaplasmosis associated with the presence of different Anaplasma marginale strains in dairy cattle in the states of São Paulo and Goiás, Brazil. Rev Bras Parasitol Vet 2015; 24(4): 438-446. http://dx.doi. org/10.1590/S1984-29612015078. PMid:26648009.

Molad T, Fleidrovich L, Mazuz M, Fish L, Leibovitz B, Krigel Y, et al. Genetic diversity of major surface protein 1a of Anaplasma marginale in beef cattle. Vet Microbiol 2009; 136(1-2): 54-60. http://dx.doi. org/10.1016/j.vetmic.2008.10.025. PMid:19081688.

Palmer GH, Rurangirwa FR, Kocan KM, Brown WC. Molecular basis for vaccine development against the ehrlichial pathogen Anaplasma marginale. Parasitol Today 1999; 15(7): 281-286. http://dx.doi.org/10.1016/S01694758(99)01469-6. PMid:10377531.

Pohl AE, Cabezas-Cruz A, Ribeiro MFB, Silveira JAG, Silaghi C, Pfister $\mathrm{K}$, et al. Detection of genetic diversity of Anaplasma marginale isolates in Minas Gerais, Brazil. Rev Bras Parasitol Vet 2013; 22(1): 129-135. http:// dx.doi.org/10.1590/S1984-29612013000100024. PMid:24252959.

Rodríguez-Vivas RI, Miller RJ, Ojeda-Chi MM, Rosado-Aguilar JA, Trinidad-Martínez IC, Pérez de León AA. Acaricide and ivermectin resistance in a field population of Rhipicephalus microplus (Acari: Ixodidae) collected from red deer (Cervus elaphus) in the Mexican tropics. Vet Parasitol 2014; 200(1-2): 179-188. http://dx.doi.org/10.1016/j.vetpar.2013.11.025. PMid:24365245.

Sanger F, Nicklen S, Coulson AR. DNA Sequencing with chain termination inhibitors. Proc Natl Acad Sci USA 1977; 74(12): 5463-5467. http:// dx.doi.org/10.1073/pnas.74.12.5463. PMid:271968.

Silva JB, André MR, Machado RZ. Low genetic diversity of Anaplasma marginale in calves in an endemic area for bovine anaplasmosis in the state of São Paulo, Brazil. Ticks Tick Borne Dis 2016; 7(1): 20-25. http:// dx.doi.org/10.1016/j.ttbdis.2015.07.018. PMid:26318264.

Silva JB, Gonçalves LR, Varani AM, André MR, Machado RZ. Genetic diversity and molecular phylogeny of Anaplasma marginale studied longitudinally under natural transmission conditions in Rio de Janeiro, Brazil. Ticks Tick Borne Dis 2015; 6(4): 499-507. http://dx.doi.org/10.1016/j. ttbdis.2015.04.002. PMid:25985719.

Souza Ramos IA, Herrera HM, Fernandes SJ, Amaral RB, Zanatto DCS, Silva TMV, et al. Genetic diversity of Anaplasma marginale in beef cattle in the Brazilian Pantanal. Ticks Tick Borne Dis 2019; 10(4): 805-814. http://dx.doi.org/10.1016/j.ttbdis.2019.03.015. PMid:30930114.

Vidotto MC, Kano SF, Gregori F, Headley SA, Vidotto O. Phylogenetic analysis of Anaplasma marginale strains from Paraná State, Brazil, using the mspl $\alpha$ and msp4 genes. J Vet Med 2006; 53(9): 404-411. http://dx.doi. org/10.1111/j.1439-0450.2006.00984.x. PMid:17062116. 